\title{
PEMANFAATAN SAMPAH ANORGANIK UNTUK MENUNJANG MEBEL ANTI RAYAP, JAMUR DAN BAKTERI DI DESA BLADO KULON KECAMATAN TEGAL SIWALAN KABUPATEN PROBOLINGGO
}

\section{Utilization Of Anorganic Waste To Support Anti Rayap, Fungus And Bacterial Furniture In Blado Village, Kegon Kecamatan Tegal Siwalan, Probolinggo Regency}

\author{
Imam Marzuki ${ }^{1)}$, Misdiyanto ${ }^{2)}$, Hermanto ${ }^{3)}$ \\ ${ }^{1,2}$ Program Studi Teknik Elektro, Fakultas Teknik, Universitas Panca Marga \\ ${ }^{3}$ Program Studi Manajemen, Fakultas Teknik, Universitas Panca Marga \\ Email: imam@upm.ac.id ${ }^{1)}$
}

\begin{abstract}
ABSTRAK
Banyaknya sampah yang berserakan telah menjadi ide dasar dalam pengabdian ini. Secara terminologi sampah tersebut dibagi menjadi sampah organik maupun sampah anorganik. Sampah dapat menyebabkan berbagai macam masalah, diantaranya menyebabkan lingkungan menjadi kotor, menyebabkan bencana banjir apabila menyumbat aliran sungai, bahkan bisa mencemari lingkungan dengan bau yang ditimbulkan. Oleh karena itu, muncullah gagasan untuk mengorganisir sampah hasil pembuangan rumah tangga, toko, maupun industri. Mengorganisir sampah organik amatlah mudah karena sifatnya yang mudah terurai. Namun, hal tersebut tidak berlaku dengan sampah anorganik. Sampah anorganik tidak bisa diuraikan, oleh karena itu diperlukan teknik khusus untuk menanganinya. Tempat tinggal mitra dalam pengabdian ini adalah di desa Blado Kulon kecamatan Tegal Siwalan kabupaten Probolinggo. Mitra sehari-hari membuka usaha mebel yang bahan dasarnya dari kayu. Namun pengusaha merasa kesulitan menemukan ciri khas dari mebel buatannya yang membedakan dari mebelmebel lainnya. Disisi lain pengusaha juga tidak mampu memasarkan produknya secara optimal. Hal ini dikarenakan selain tidak memiliki ciri khas, koneksi dengan orang banyak juga tidak dimiliki pengusaha dalam memasarkan produknya. Berkaca terhadap permasalahan yang dihadapi mitra dan demi menjaga lingkungan tetap bersih dari sampah khususnya sampah anorganik, maka pengabdian ini di fokuskan pada pemanfaatan sampah anorganik untuk menunjang usaha mebel anti rayap, bakteri dan jamur. Teknik yang dilakukan adalah mengumpulkan sampah anorganik, mengeringkannya dan kemudian membakarnya di tungku pembakaran yang telah disiapkan. Selanjutnya asap hasil pembakaran disimpan dengan alat penyimpan asap untuk kemudian asap di berikan kepada kayu bahan pembuat mebel. Teknik ini menurut beberapa penelitian dapat membuat mebel tahan rayap, bakteri, dan jamur. Setelah produk dihasilkan maka pengusaha dibantu dengan teknik pemasaran online (e-commerce). Hal ini bertujuan agar mempermudah pengusaha memasarkan produknya dalam jangkauan yang luas.
\end{abstract}

Kata Kunci : sampah anorganik, asap, mebel, e-commerce

\begin{abstract}
The amount of garbage scattered has become a basic idea in this service. In terminology, the waste is divided into organic and inorganic waste. Garbage can cause various kinds of problems, including causing the environment to become dirty, causing floods if it clogs up the flow of the river, and can even pollute the environment with the odor generated. Therefore, the idea emerged to organize household waste, household and shop disposal. Organizing organic waste is very easy because it is easily decomposed. However, this does not apply to inorganic waste. Inorganic waste cannot be decomposed, so special techniques are needed to handle it. The residence of the partner in this service is in the village of Blado Kulon, Tegal Siwalan district, Probolinggo district. Everyday partners open a furniture business which is made from wood. But entrepreneurs find it difficult to find the characteristics of their furniture that distinguishes it from other furniture. On the other hand entrepreneurs are also unable to market their products optimally. This is because in addition to not having its own characteristics, connections with many people are also not owned by entrepreneurs in marketing their products. Reflecting on the problems faced by partners and in order to keep the environment clean of rubbish, especially inorganic rubbish, this service is focused on the use of inorganic rubbish to support the business of termite, bacterial and fungal furniture. The technique used is collecting inorganic waste, drying it and then
\end{abstract}


burning it in a prepared furnace. Furthermore, the combustion fumes are stored with a smoke storage device and then the smoke is given to wood furniture making materials. This technique, according to several studies, can make termite, bacteria, and fungus resistant furniture. After the product is produced, entrepreneurs are assisted with online marketing techniques (e-commerce). It aims to make it easier for entrepreneurs to market their products in a wide range.

Keywords: inorganic waste, smoke, furniture, e-commerce

\section{PENDAHULUAN}

Banyaknya sampah yang berserakan telah menjadi ide dasar dalam pengabdian ini. Secara terminologi sampah tersebut dibagi menjadi sampah organik maupun sampah anorganik. Sampah dapat menyebabkan berbagai macam masalah, diantaranya menyebabkan lingkungan menjadi kotor, menyebabkan bencana banjir apabila menyumbat aliran sungai, bahkan bisa mencemari lingkungan dengan bau yang ditimbulkan. Oleh karena itu, muncullah gagasan untuk mengorganisir sampah hasil pembuangan rumah tangga, toko, maupun industri. Mengorganisir sampah organik amatlah mudah karena sifatnya yang mudah terurai. Namun, hal tersebut tidak berlaku dengan sampah anorganik. Sampah anorganik tidak bisa diuraikan, oleh karena itu diperlukan teknik khusus untuk menanganinya.

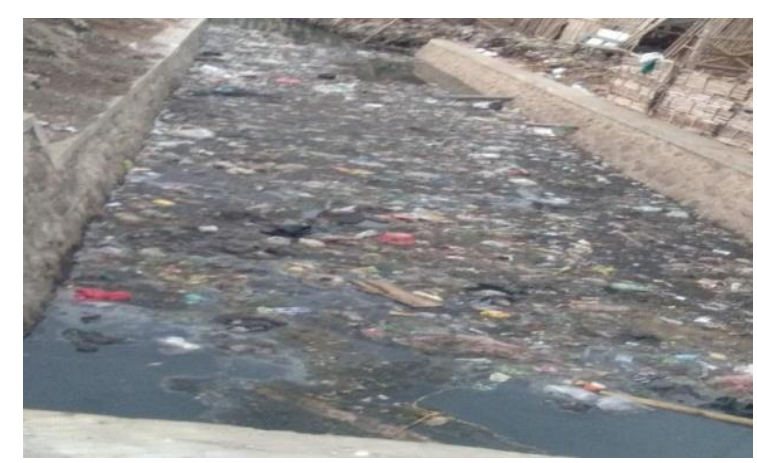

Gambar 1. Sampah yang berserakan

Mitra bernama Eko Siswanto, pemilik usaha mebel telah berkecimpung di dunia mebel sejak tahun 2016. Mitra memiliki 4 orang pegawai dengan tugas yang berbeda satu sama lain. Pegawai pertama bertugas untuk desain mebel. Pegawai kedua bertugas menyiapkan dan memperhalus kayu untuk dibuat mebel sesuai dengan yang didesain. Pegawai ketiga mewujudkan kayu sesuai dengan desain. dan pegawai keempat bertugas untuk mengecat mebel yang telah dibuat.

Tempat tinggal mitra dalam pengabdian ini adalah di desa Blado Kulon kecamatan Tegal Siwalan kabupaten Probolinggo. Mitra sehari-hari membuka usaha mebel yang bahan dasarnya dari kayu. Namun pengusaha merasa kesulitan menemukan ciri khas dari mebel buatannya yang membedakan dari mebel-mebel lainnya. Disisi lain pengusaha juga tidak mampu memasarkan produknya secara optimal. Hal ini dikarenakan selain tidak memiliki ciri khas, koneksi dengan orang banyak juga tidak dimiliki pengusaha dalam memasarkan produknya.

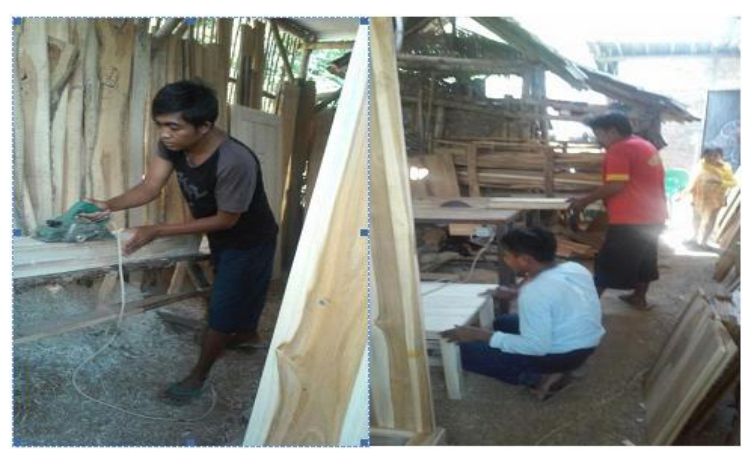

Gambar 2. Aktivitas pegawai mebel

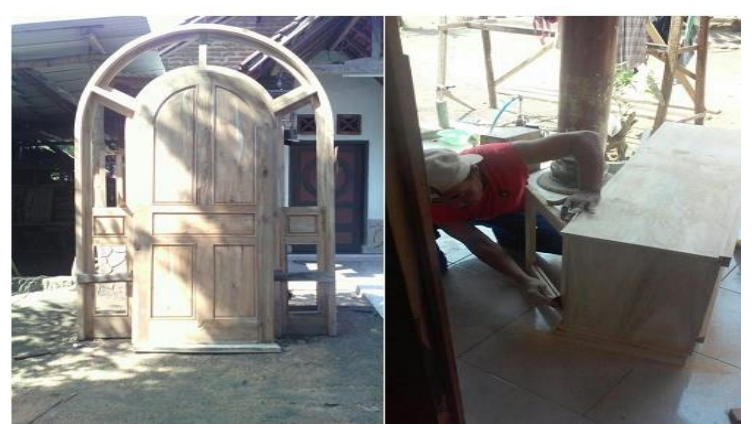

Gambar 3. Mebel yang sudah diwujudkan sesuai desain 


\section{SOLUSI DAN TARGET LUARAN}

\section{Solusi Yang Ditawarkan}

Berkaca terhadap permasalahan yang dihadapi mitra dan demi menjaga lingkungan tetap bersih dari sampah khususnya sampah anorganik, maka pengabdian ini di fokuskan pada pemanfaatan sampah anorganik untuk menunjang usaha mebel anti rayap, bakteri dan jamur. Teknik yang dilakukan adalah mengumpulkan sampah anorganik, mengeringkannya dan kemudian membakarnya di tungku pembakaran yang telah disiapkan. Selanjutnya asap hasil pembakaran disimpan dengan alat penyimpan asap untuk kemudian asap di berikan kepada mebel yang telah dihasilkan. Teknik ini menurut beberapa penelitian dapat membuat mebel tahan rayap, bakteri, dan jamur.

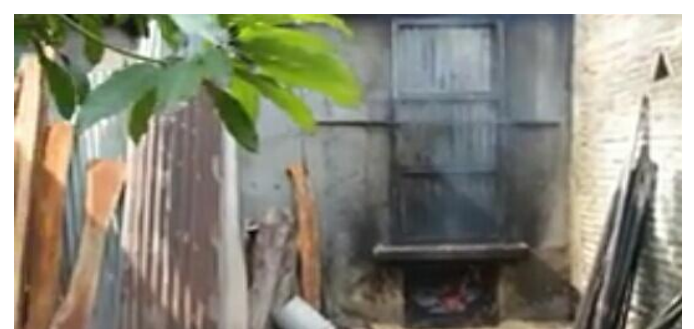

Gambar 4. Pengasapan kayu bahan mebel dengan sampah anorganik yang dibakar

Setelah produk dihasilkan maka pengusaha dibantu dengan teknik pemasaran online (ecommerce). Hal ini bertujuan agar mempermudah pengusaha memasarkan produknya dalam jangkauan yang luas.

\section{Target Luaran}

Luaran yang diharapkan dari program ini adalah :

a. Terwujudnya teknologi tepat guna alat pembakar sampah anorganik dan penghasil sampah

b. Terbangunnya sebuah toko online guna memasarkan mebel hasil karya mitra
Kondisi yang diharapkan setelah program kemitraan ini terlaksana tertuang dalam tabel 2.1

Tabel 1. Kondisi mitra setelah program PKM dilaksanakan

\begin{tabular}{|l|l|l|}
\hline No & $\begin{array}{l}\text { Kondisi } \\
\text { Sebelum }\end{array}$ & Kondisi Setelah \\
\hline 1 & $\begin{array}{l}\text { Tidak adanya } \\
\text { ciri khas mebel } \\
\text { buatan mitra } \\
\text { dengan mebel- } \\
\text { mebel lainnya }\end{array}$ & $\begin{array}{l}\text { Mebel diklaim anti } \\
\text { rayap, bakteri dan } \\
\text { jamur sehingga } \\
\text { lebih tahan lama } \\
\text { dan awet }\end{array}$ \\
\hline 2 & $\begin{array}{l}\text { Belum } \\
\text { optimalnya } \\
\text { pemasaran }\end{array}$ & $\begin{array}{l}\text { Pemasaran } \\
\text { dilakukan melalui } \\
\text { toko online yang } \\
\text { dapat dilakukan } \\
\text { kapanpun dan } \\
\text { dimanapun }\end{array}$ \\
\hline
\end{tabular}

Selain luaran yang telah disebutkan sebelumnya, terdapat luaran lain yang diharapkan seperti yang dituangkan dalam tabel 2.2.

Tabel 2. Rencana Target Capaian Luaran.

\begin{tabular}{|l|l|l|}
\hline No & Jenis Luaran & $\begin{array}{l}\text { Indikator } \\
\text { Capaian }\end{array}$ \\
\hline 1 & $\begin{array}{l}\text { Publikasi ilmiah } \\
\text { Pada Jurnal } \\
\text { Nasional } \\
\text { BerISSN }\end{array}$ & Terbit \\
\hline 2 & $\begin{array}{l}\text { Publikasi pada } \\
\text { media elektronik } \\
\text { (repository } \\
\text { kampus) }\end{array}$ & Ada \\
\hline 3 & $\begin{array}{l}\text { Video } \\
\text { dokumentasi } \\
\text { pada media } \\
\text { elektronik } \\
\text { (repository } \\
\text { kampus) }\end{array}$ & Ada \\
\hline 4 & $\begin{array}{l}\text { Hak kekayaan } \\
\text { intelektual (Hak } \\
\text { Cipta program } \\
\text { komputer "Toko } \\
\text { Online") }\end{array}$ & \\
\hline
\end{tabular}




\section{METODE PELAKSANAAN KEGIATAN}

Prosedur Metode pelaksanaan yang ditawarkan sebagai bentuk penerapan PKM yang dianggap sesuai adalah menyusun beberapa program antara lain mengumpulkan referensi mengenai macammacam teknologi yang akan digunakan, spesifikasinya, pengetahuan tentang inovasi teknologi yang tepat guna serta menguji apakah teknologi yang digunakan tersebut mampu bekerja sesuai dengan yang diinginkan. Dari solusi atas prioritas permasalahan yang telah disepakati dengan mitra, maka langkah-langkah konkret diaplikasikan dalam beberapa bentuk kegiatan. Rencana kegiatan program PKM tersebut adalah:

1. Diskusi dan Pengumpulan Referensi Diskusi antara tim pelaksana dan mitra tentang solusi dari permasalahan yang ada.

2. Pengumpulan Referensi

Mengumpulkan referensi tentang pembuatan toko online untuk UMKM.

3. Implementasi Toko Online Mewujudkan toko online sesuai referensi.

4. Uji coba Website

Menguji coba website yang sudah dibuat pada mitra untuk mengecek kemampuan website tersebut dalam membuat jaringan calon konsumen.

5. Melaksanakan Pelatihan Keterampilan Komputer Administrasi dan Keterampilan Komputer Berbasis Internet terkait penggunaan toko online.

6. Merancang dan Membuat Alat Pembakar Sampah Anorganik dan Penghasil Asap

7. Melaksanakan Pendampingan Pembakaran Sampah Anorganik dan Memberi Asap Pada Kayu Bahan Mebel. Pendampingan ini bertujuan untuk partisipasi mitra dalam pelaksanaan program.
Dalam pelaksanaan kegiatan PKM ini membutuhkan partisipasi aktif dari mitra. Bentuk partisipasi mitra antara lain :

a. Berdiskusi dengan tim pelaksana dalam mencari solusi permasalahan dengan memberikan masukanmasukan dari pengalaman selama melakukan usaha pembuatan mebel

b. Ikut memberikan masukan dalam merancang alat pembakaran sampah anorganik dan penghasil asap

c. Ikut memberikan masukan dalam merancang toko online pemasaran

d. Ikut serta dalam uji coba alat pembakaran sampah anorganik dan penghasil asap

e. Ikut serta dalam uji coba website

f. Menyiapkan tenaga kerja untuk dilatih dalam mengoperasikan toko online yaitu seorang Customer Service yang khusus menangani pemasaran melalui toko online

\section{HASIL DAN PEMBAHASAN}

Dalam kegiatan PKM yang telah dilakukan, luaran yang telah didapatkan dan yang akan ditransfer ke mitra, diantaranya :

1. Teknologi Tepat Guna "Alat Pembakar Sampah Anorganik dan Penghasil Asap". Gambar alat dapat ditunjukkan pada gambar 5 .

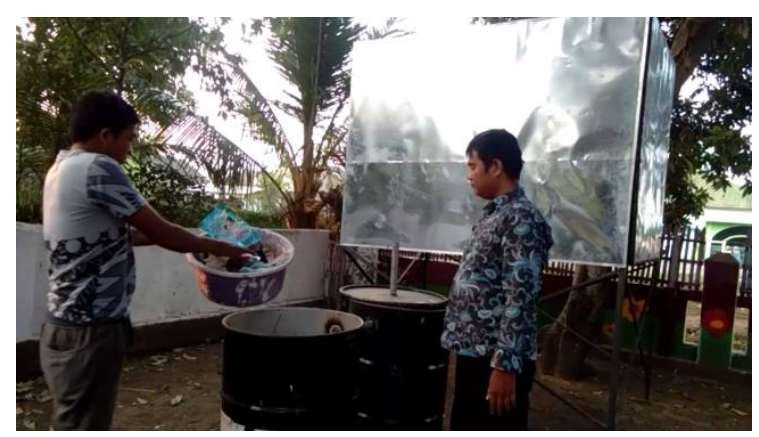

Gambar 5. Uji coba teknologi tepat guna "alat pembakar sampah anorganik dan penghasil asap" 
Pada gambar 5, uji coba dilakukan bersama mitra. Hal ini dilakukan agar mitra dapat mengerti cara kerja alat yang dihasilkan dalam PKM ini.

Setelah sampah anorganik terbakar, maka asap akan mengalir ke bagian selanjutnya dan terakhir akan tertampung didalam kotak yang berukuran 2 meter $^{2}$. Setelah itu mitra dapat meletakkan kayu bahan mebel ke kotak tersebut. Kayu bahan mebel yang dimasukkan ke dalam kotak dapat ditunjukkan pada gambar 6 .

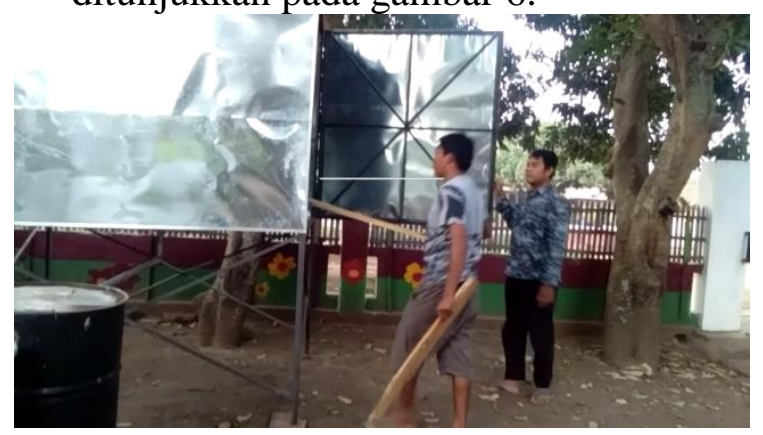

Gambar 6. Kayu bahan mebel yang dimasukkan ke dalam kotak yang terkumpul asap

2. Toko Online untuk Penjualan Mebel buatan Mitra dengan Tampilan di Komputer dan Laptop. Toko online ini bisa ditunjukkan pada gambar 7 .

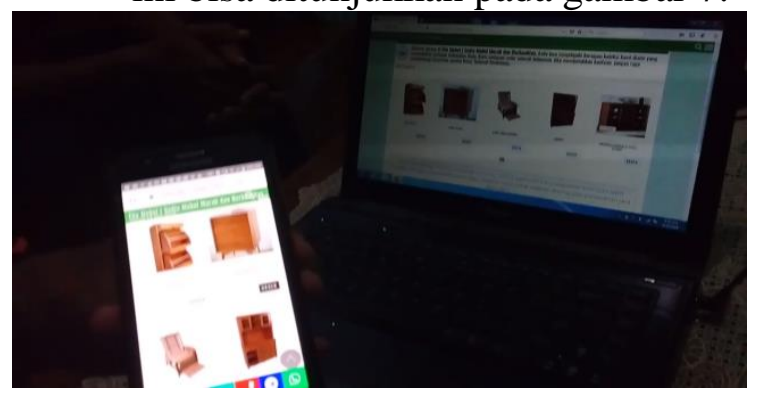

Gambar 7. Toko online penjualan mebel dengan tampilan di komputer/laptop dan smartphone android

Toko online yang dihasilkan pada gambar 7 ditransfer ke mitra dengan cara pelatihan dan pendampingan tentang tata cara penggunaan. Pelatihan dan pendampingan ini disertai dengan penyerahan akun toko online yang selanjutnya dapat dikelola mitra secara mandiri.

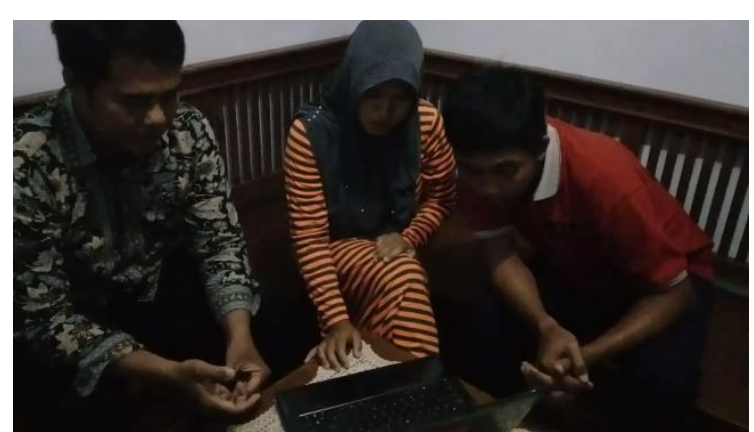

Gambar 8. Pelatihan dan pendampingan tata cara penggunaan toko online

\section{KESIMPULAN DAN SARAN}

\section{Kesimpulan}

Kegiatan Pelaporan Kemajuan Program Kemitraan Masyarakat (PKM) Tahun Anggaran 2019 untuk masyarakat pengusaha mebel dengan judul PKM "Pemanfaatan Sampah Anorganik Untuk Menunjang Mebel Anti Rayap, Jamur dan Bakteri di Desa Blado Kulon Kecamatan Tegal Siwalan Kabupaten Probolinggo" berjalan dengan baik dan lancar sesuai dengan rencana. Hasil yang didapat dari kegiatan Pelaporan kemajuan PKM ini adalah:

1. Teknologi Tepat Guna yang akan ditransfer ke mitra "Alat Pembakar Sampah Anorganik dan Penghasil Asap".

2. Toko Online Untuk Mengoptimalkan Pemasaran Mebel.

\section{Saran}

Program pengabdian masyarakat merupakan salah satu kewajiban Tri Darma Perguruan Tinggi yang wajib dipenuhi oleh seorang dosen. Oleh karena itu, Kemenristekdikti hendaknya dapat mempertimbangkan untuk meningkatkan anggaran pada program ini sehingga semakin banyak kesempatan yang dimiliki dosen untuk mendapatkan program hibah. Selain itu skema pada pengabdian agar sedapat mungkin diperluas karena masih banyak masyarakat yang membutuhkan 
teknologi tepat guna yang bisa ditransfer dari program pengabdian ini.

\section{DAFTAR PUSTAKA}

Anonimous. 2018. Pengertian dan Pengelolaan Sampah Organik dan Anorganik.

https://solusinya.net/sampah-organikdan-anorganik/

Akbar OT. 2009. Ketahanan Kayu Yang Diawetkan Dengan Pengasapan Dari Serangan Rayap Tanah dan Rayap Kayu Kering. Skripsi Sarjanan Kehutanan Institut Pertanian Bogor

Anonimous. 2018. Cara Membuat Website Sederhana Untuk Pemula dalam 5 Menit, berguruseo.blogspot.com/2013/12

Anonimous. 2018. Mebel. https://id.wikipedia.org/wiki/Mebel 